\title{
TECTONIC PATTERNS IN THE CENTRAL BALTIC SHIELD
}

\author{
Heikni V. Tuominen, Jussi Aarnisalo and Bengt Söderholm
}

Heikki V. Tuominen, Jussi Aarnisalo and Bengt Söderholm 1973: Tectonic patterns in the central Baltic Shield. Bull. Geol. Soc. Finland 45, 205-217.

A network of several sets of subparallel lineaments, extending over the Baltic Shield into the surrounding areas of Paleozoic and later rocks, has been identified in Nimbus satellite imagery. The observed lengths of several lineaments exceed $1000 \mathrm{~km}$. Each set is distributed all over the Shield. Ground data collected in Finland indicate the following. The strikes of foliation of the Precambrian schists and gneisses are concentrated into eight dominant trends, each parallel to a given set of the lineaments. The strike frequency maxima of the Bouguer gravity isolines and the dominant trends of the basement scarps and trenches fall in these same directions. Schist belts, ranging in age up to 2800 m.y., as well as the boundaries of the major structural and lithologic units, are aligned with or parallel to the lineaments, which also separate blocks differing in altitude and in rate of recent land-uplift. The data suggest that the lineaments represent a permanent abyssal shear-net system, which has contributed to the evolution of the Shield since Early Precambrian times. The system possibly extends over the surrounding ocean floor.

Heikki V. Tuominen, Department of Geology and Mineralogy, University of Helsinki, SF-00170 Helsinki 17, Finland.

Jussi Aarnisalo, Department of Geology and Mineralogy, University of Helsinki, SF-00170 Helsinki 17, Finland.

Bengt Söderbolm, Department of Mining and Metallurgy, Helsinki University of Technology, SF-02150 Otaniemi, Finland.

\section{Introduction}

Small-scale geological and other maps of the Baltic Shield suggest that the general strikes of the schist belts, rock boundaries and morphologic lineaments are parallel and concentrated in certain dominant directions. This is supported by various geophysical maps. (Tuominen 1957,
1962, 1966; Tuominen and Söderholm 1966, Marmo 1959, Paarma and Marmo 1961, Paarma 1963, Mikkola and Niini 1968, Aarnisalo et al. 1969).

The authors have tested this parallelism in different ways. Nimbus satellite imagery was used to identify the major morphologic trends and lineaments. The structural characteristics 
were studied by analyzing various geological and geophysical maps and data of Finland, relating to the central part of the Shield. An analysis of the foliation trends and fracture line trends was made by Söderholm (1970) and an analysis of gravity isoline trends by Aarnisalo (1969). The latter also studied the relationships between the ancient crustal structures and the recent uplift of the Shield (Aarnisalo 1971). The present paper is mainly a synthesis of the results of these three unpublished theses.

The work was carried out under the leadership of the author Tuominen. The results are tentative and are being tested in the framework of an ERTS-1 program (Tuominen $1973 \mathrm{a}$ and b).

\section{Nimbus imagery}

Application of space-borne Earth observations has led to the discovery of a great number of major geological structures, which, even in the most thoroughly investigated regions, have escaped detection earlier. For instance, some major strike-slip faults transecting the Alps were first detected from lineaments in ERTS imagery (Bodechtel and Lammerer 1973). Lineaments of still wider dimensions and of established geological significance have been identified in Nimbus imagery (Sabatini et al. 1971, Lathram 1972).

Parts of two Nimbus pictures obtained over Fennoscandia are seen in Figs. 1 and 2. Several intersecting sets of subparallel lineaments are visible in these pictures. Particularly clear is a northwesterly set, which appears to have been most suitably illuminated at the Satellite crossing time; one of these lineaments is seen to extend from the Fjord Malangen on the Norwegian coast $1000 \mathrm{~km}$ to the south coast of the White Sea (Fig. 1).

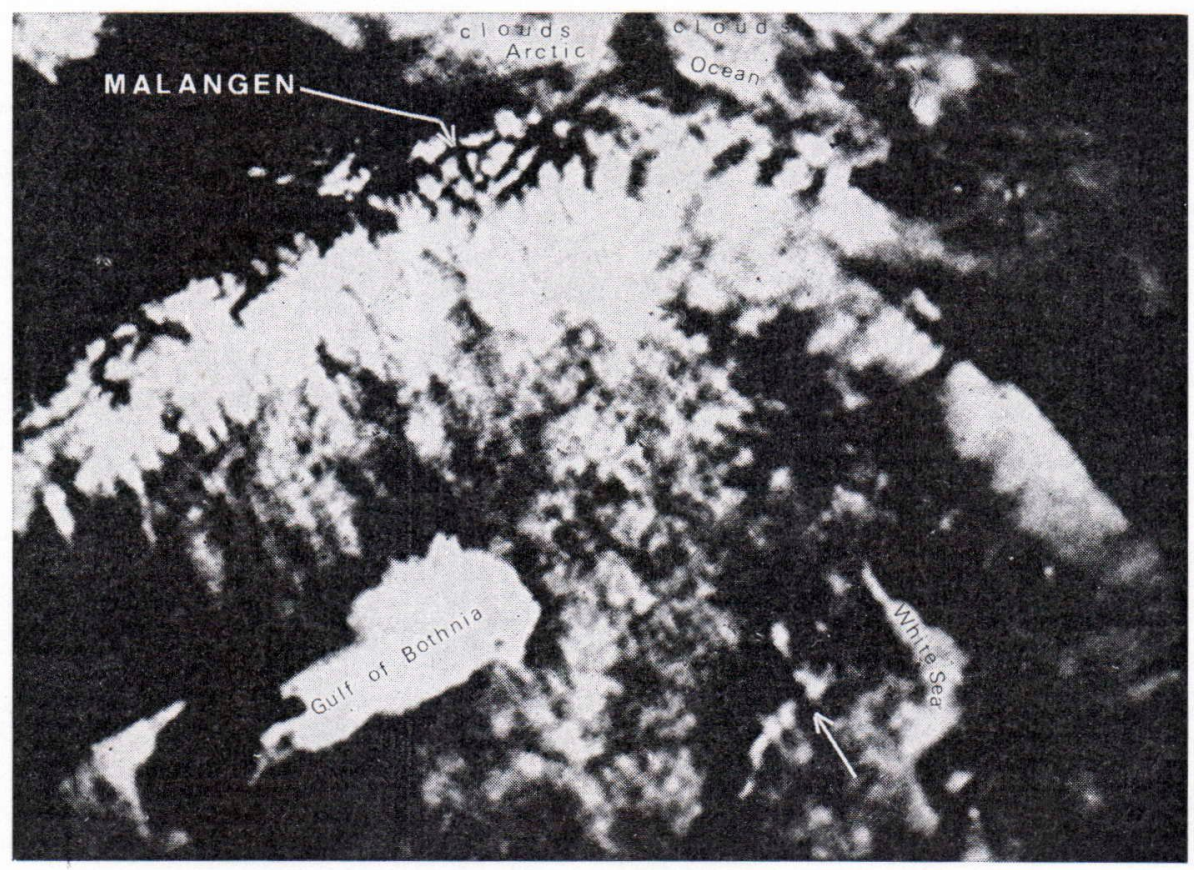

FIG. 1. Part of a Nimbus-3 photograph of northern Fennoscandia. (Received 25 April 1969, 08.15 GMT by Radio Laboratory, Helsinki University of Technology. Scan-lines eliminated by optical filtering). A lineament extending from Malangen, Norway, to the south side of White Sea is indicated by arrows. A great number of lineaments in this and other directions are discernible. Parts of Gulf of Bothnia and White Sea covered by ice. 


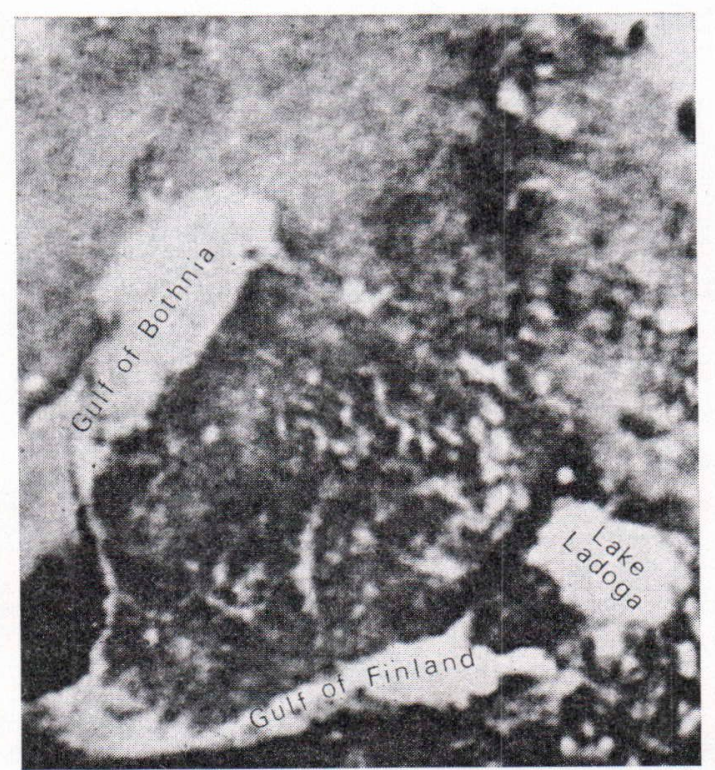

FIG. 2. Part of a Nimbus-4 photograph showing southern Finland. (Finnish Meteorological Institute, 5 March 1972, 08.24 GMT. Scan-lines eliminated). A northwesterly $\left(310^{\circ}\right)$ line of ice- and snowcovered lakes and bogs, extending from Lake Ladoga to Gulf of Bothnia, marks a major Precambrian fracture zone. Several other lineaments of this trend are visible. Distinct lineaments occur parallel to each shore-line trend.

The pictures were obtained on low-sun-angle/ winter conditions when the ground and the frozen lakes, but not the tree-tops, were covered with snow. The lineaments consist of lines of lakes, rivers, bogs and fields, of zones of dense conifer forests and, where the relief is high, of shadows at scarps and canyons. As a rule, these zones coincide with valleys and other morphologic features resulting from strongly fractured bedrock.

Some of the lineaments coincide with zones which have been attributed to abyssal fractures of Early Precambrian origin (Salop and Scheinmann 1969, Petrov 1970, Penttilä 1972).

\section{Foliation trends}

The trends of foliation were analyzed from observations made in different parts of Finland during the forty years preceding 1969. Most of the observations are from the latter half of this time; about one half were collected from the Geological Map of Finland (1:100 000) and from maps contained in published papers, and the other half from unpublished maps, field notes and academic theses.

In the present paper, as in the geological maps used, the streaky or banded structures of gneisses and migmatites, in addition to schistosity, are included in foliation.

The strikes of gently dipping structures generally fluctuate within wide limits. To avoid dispersive values of this sort, observations with a dip of less than 40 degrees were not used. For this reason about $6.6 \%$ of the observations available were discarded. The remaining 100450 were used in the analysis.

Because of great regional variation in the observation density, the observations were analyzed, with few exceptions, according to the quadrangles of the Geological Map of Finland, 1:100 000. In the areas concerned the size of these quadrangles varies from $30 \times 30 \mathrm{~km}^{2}$ to $40 \times 30 \mathrm{~km}^{2}$, depending on position. In some areas, however, overlapping unit areas about four times this size were used because of low observation density. Altogether 151 quadrangles or other unit areas were investigated, of which 141 were free from overlap or common data. No usable data were obtained for the area north of the 67 th parallel.

The azimuthal distribution of the strikes indicates that, on average, about 70 percent of the original compass readings had been expressed in tens of degrees, and readings evenly divisible by thirty (i.e., $360,30,60,90$, etc.) are generally more frequent than the other ten degree readings. These features result mainly from the rounding off of the readings. The observations have been made with a type of compass on which only each thirtieth degree is numbered. In consequence, the thirty-degree readings have been apt to be used as approximations for fluctuating strikes that cannot be measured accurately. 


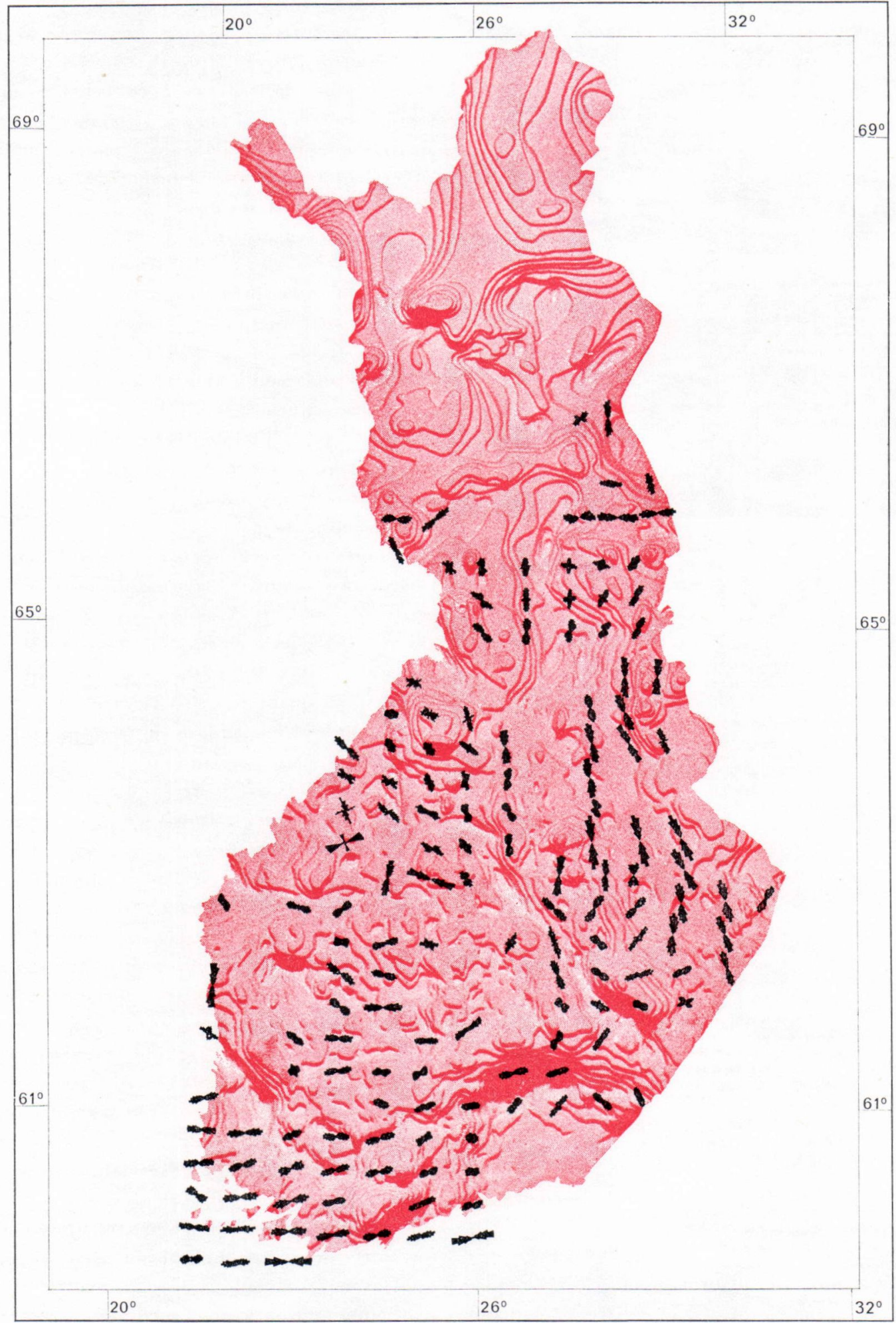

FrG. 3. Foliation rosettes on a relief-model photograph of the Bouguer gravity map of Finland. Oblique illumination from the north. 
To eliminate this effect, the frequency at each ten-degree interval, centered at the original tendegree readings, was replaced by the moving average of three successive frequencies. The new values thus consist of the readings from one preferred and two unpreferred ten-degree intervals. The results were normalized, corrected for declination, and presented in rose diagrams. In Fig. 3 the resulting 151 diagrams are superposed on a relief-model photograph made after Honkasalo's (1962) Bouguer-anomaly map of Finland.

In most of the diagrams there is a distinct main maximum corresponding to the trend of foliation dominant in the particular area. Subordinate trends are indicated by minor maxima in the same diagrams. Owing to summation of partially mixed distributions of azimuthally adjacent trends, and to the smoothing procedure, the maxima apparently deviate more or less from the true positions, and peaks common to two adjacent trends are frequent. Such peaks are usually skewed toward the side of the less frequent trend. In spite of these and other dispersive factors, the results shown in Fig. 3 indicate that a trend dominant in any given belt normally extends as a subordinate trend through the transecting belts. Hence, for finding the general trends the directions of the main and subordinate maxima were given equal weight.

The average trends were studied from the maxima of the 141 rose diagrams in Fig. 3 which are free from common data. The total number of maxima in these diagrams is 285 , with azimuthal widths varying from ten to thirty degrees. The procedure was the following: The number of maxima present in each one-degree interval was counted, and the frequencies obtained were smoothed by ten-degree mowing averages. Fig. 4 a gives the smoothed frequencies normalized and combined into a curve. The seven peaks of this curve, together with the hump on the lefthand slope of the rightmost peak, suggest that eight main trends (I-VIII) of foliation are present in the area.

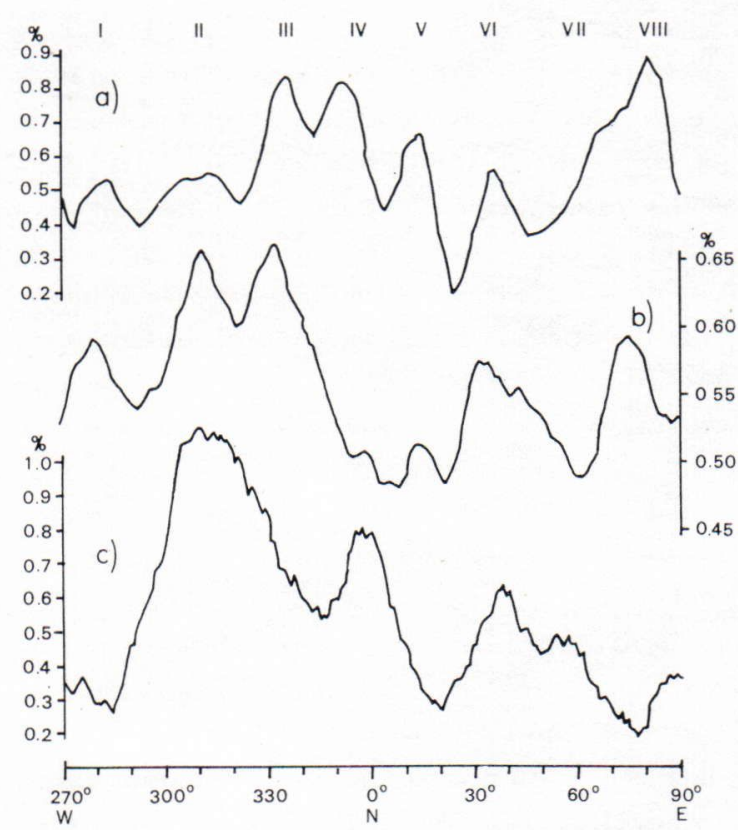

FIG. 4. Strike-frequency distribution of: (a) foliation maxima of 141 rosettes; (b) Bouguer gravity isolines; (c) fracture lines. Data from Finland between 60 th and 67 th parallel.

Whether the same eight trends exist in different parts of the area was tested by studying the average trends north and south of the 63rd parallel separately. Of the 141 diagrams, 58 (119 maxima) represent the northern and 83 (166

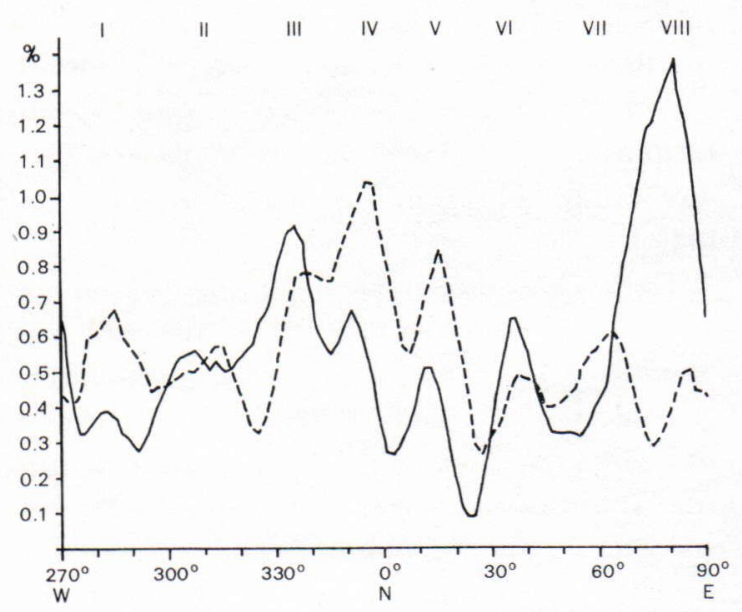

FIG. 5. Strike-frequency distribution of foliation-rosette maxima south (solid line) and north (dashed line) of 63rd parallel. Data same as in Fig. 4 a. 
maxima) the southern area. Results are given in Fig. 5. In both curves the distribution of peaks is essentially same as in Fig. 4 a. In place of the hump on the rightmost peak (VIII) there is a separate peak in the curve for the northern area, which explains the origin of the hump in Fig. 4 a. Analysis of the original data indicates that the corresponding single peak obtained for the southern area is also a sum of these two trends (VII and VIII). However, the position and shape of this peak is determined mainly by trend VIII, which in this area has the greatest weight.

This suggests that there are eight main trends of foliation distributed more or less evenly throughout the central Baltic Shield. Owing to the many smoothings required by the original data, this result may not be entirely unambiguous. In the following we shall test the validity of the result by comparison with various other data.

\section{Gravity isoline trends}

It appears from Fig. 3 that the contours of the Bouguer gravity map are frequently parallel to the trends of foliation. Gravity slopes and ramps, indicated by the straight parts of the contours, generally coincide with fold and fault zones (Romberg 1958), as do the zones of parallel foliation. In consequence, it might be expected that a frequency analysis of the directions of the gravity contours would provide a way to test the validity of the estimated trends of foliation.

The average directions of the gravity contours were analyzed from the Bouguer anomaly map of Finland, 1:1 000000 (Honkasalo 1962). The general area covered was largely the same as in the foliation analysis, i.e., the land areas of Finland south of the 67 th parallel.

A sample of the contour directions was obtained by taking the azimuths of consecutive $1-\mathrm{cm}$ chords of the contours. Each of these azimuths thus represents at least one tangential direction of the corresponding part of the contour. The azimuths were given in whole degrees and the one-degree frequencies obtained were smoothed twice by ten-degree moving averages.

The normalized results are given in Fig. 4 b. The eight peaks obtained fall consistently at the azimuths of the peaks of foliation. Trend VII, however, appears to be partly mixed with trend VI rather than with trend VIII, as in the case of foliation. Shifts like this may result from small differences in the dispersion of the data.

\section{Fracture line trends}

The Shield is transected by a dense network of fractures represented by gorges and scarps in the bedrock topography. Investigations on several shields suggest that such fractures are statistically parallel to the main trends of foliation (Badgley 1965, p. 496). Results obtained in certain areas of Finland support this view (Tuominen 1957, 1962, 1966; Tuominen and Söderholm 1966, Talvitie 1971). The fracture trends were studied from the latest fracture map of Finland (Mikkola and Niini 1968). As before, the areas north of the 67 th parallel were omitted.

The lengths of the fracture lines indicated on the map vary from 10 to $200 \mathrm{~km}$. The strike and length of each straight part of the lines were recorded from the map. The one-degree frequencies thus obtained were smoothed by tendegree moving averages. The normalized results are given in Fig. $4 \mathrm{c}$.

The positions of the main peaks of this graph correlate well with the respective peaks for the gravity isolines and foliation. Trend III, however, which is clearly discernible in the fracture map, is indicated in the curve only by a slight bulge on the right-hand slope of peak II. Trend V also appears to merge into peak IV. These and some other features of the graph apparently reflect the results of glacial scouring, which has been most effective on fractures in the azimuthal range from 300 to 360 degrees. 


\section{Distribution of outcrops}

The block structure and fracture patterns of the basement are clearly reflected in the distribution of outcrops in southern Finland, Fig. 6 (Aarnisalo 1971).

This map shows, on a small scale, all the outcrops indicated in the General Geological Map of Finland, Quarternary Deposits, 1:400 000 (1906-1953) and, for the southernmost areas, in the Geological Map of Finland 1:200 000
(1879-1900). The join of these maps coincides approximately with the 61st parallel and can be traced in Fig. 6. But neither this nor the quadrangle division of the maps has any major influence on the general appearance of the picture. Although these maps do not indicate all the outcrops, they give the most uniform picture so far available of the outcrop distribution in southern Finland.

The regional differences in outcrop density (Fig. 6) depend on several factors. The coastal

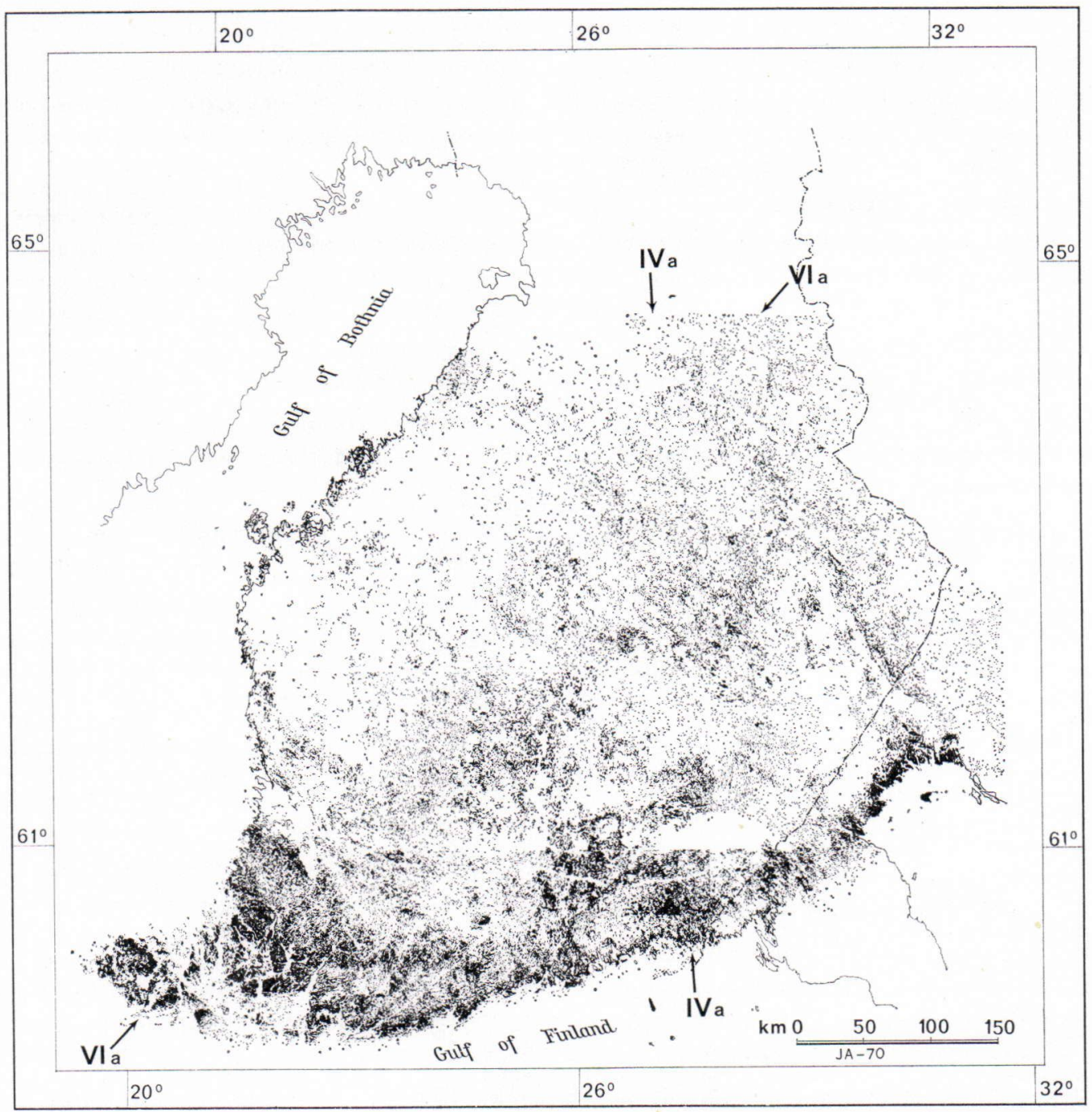

FIG. 6. Distribution of bedrock outcrops (black) in southern Finland. 
regions of the Gulf of Finland and the Gulf of Bothnia show the greatest difference in this respect. The smaller number of outcrops in the latter area apparently results from a lower mean level of the basement and higher rates of postglacial sedimentation and land uplift; the fast retreat of the sea in consequence of the rapid land uplift and flat topography has protected the sediment cover from coastal erosion. Poorly exposed are also the higher areas which, since the melting of the continental ice, have remained above the level of the Baltic Sea (see: Sauramo 1929, p. 65).

The boundaries between the areas of different outcrop density represent more or less clearcut, straight fault lines. The narrow gaps free from outcrops, as well as the narrow rows of outcrops coinciding with scarps and ramps, seen in Fig. 6, are also indicative of faults (cf., Tuominen 1957). Some of the gaps are eskers or end moraines. They, too, coincide with fracture or fault zones (Hyyppä 1951, 1954; Härme 1961, Paarma and Marmo 1961).

A good many of the individual fault lines or zones are seen to extend across the area of Fig. 6 . Two sharp lines that may not immediately catch the eye are indicated on the map by the arrows $\mathrm{VIa}$ and IVa (see also Plate 2). The latter line, which deviates about two degrees west of north, is best seen by viewing the map obliquely from the south. It is also revealed by ERTS-1 imagery. The Roman numerals refer to the trends indicated in Fig. 4, which also apply to the main fault and shore-line trends reflected in Fig. 6.

\section{Distribution of land uplift}

The distribution of land uplift indicated by precise levellings made in Finland (Kääriäinen 1963, 1966, see also Honkasalo 1960) suggests that the recent uplift of the Shield is taking place en bloc (Paarma 1963, Härme 1963, 1966). Talvitie's (1971) evidence from the Kuopio region indicates that these movements are concentrated into rejuvenated Precambrian fault zones (see also: Bogdanov and Khodotov 1967).

In order to study the deviation of land uplift values from a smooth run, a grid of equilateral triangles of $16 \mathrm{~km}$ side length was placed on Kääriäinen's (1963) isobase map. The uplift value at each grid point was read from the isobases. The arithmetic means of the six values at $48 \mathrm{~km}$ radius from each grid point then were subtracted from the values at these points. The residual uplift values thus obtained were combined into an isobase map, Plate 1 (in the folder). In the coastal zone the mean uplift values were obtained from 4 or 5 points only. These isobases are indicated by dashed lines. The map is transparent for easy comparison with the other maps of the paper.

The main directions of the isobases and gradient zones in this map, too, seem to conform with the trends discussed. In many cases the gradient zones coincide with the schist belts or with the boundaries between the schist belts and major plutons (Fig. 7). On the other hand, a good correlation is seen between the residual land uplift and the block-and-fault structures (Fig. 6). For instance, a triangular fault block mid-way along the coast of the Gulf of Finland correlates with an area of negative residual uplift. The northwestern boundary of this block coincides with the Porkkala-Lahti fault described, for instance, by Härme (1960, 1961).

A northwesterly zone of negative residual uplift extends from Lake Ladoga to the Gulf of Bothnia. The northeastern slope of this zone coincides with a deep gravity trough (Fig. 3) which separates it from areas of higher uplift northeast of the trough. This gravity trough, attributed to deep faults by several authors (Paarma and Marmo 1961, Mikkola and Niini 1968, Talvitie 1971), zigzags in line with four of the main trends (I-IV) described. The zigzags coincide with long faults belonging to these trends. 


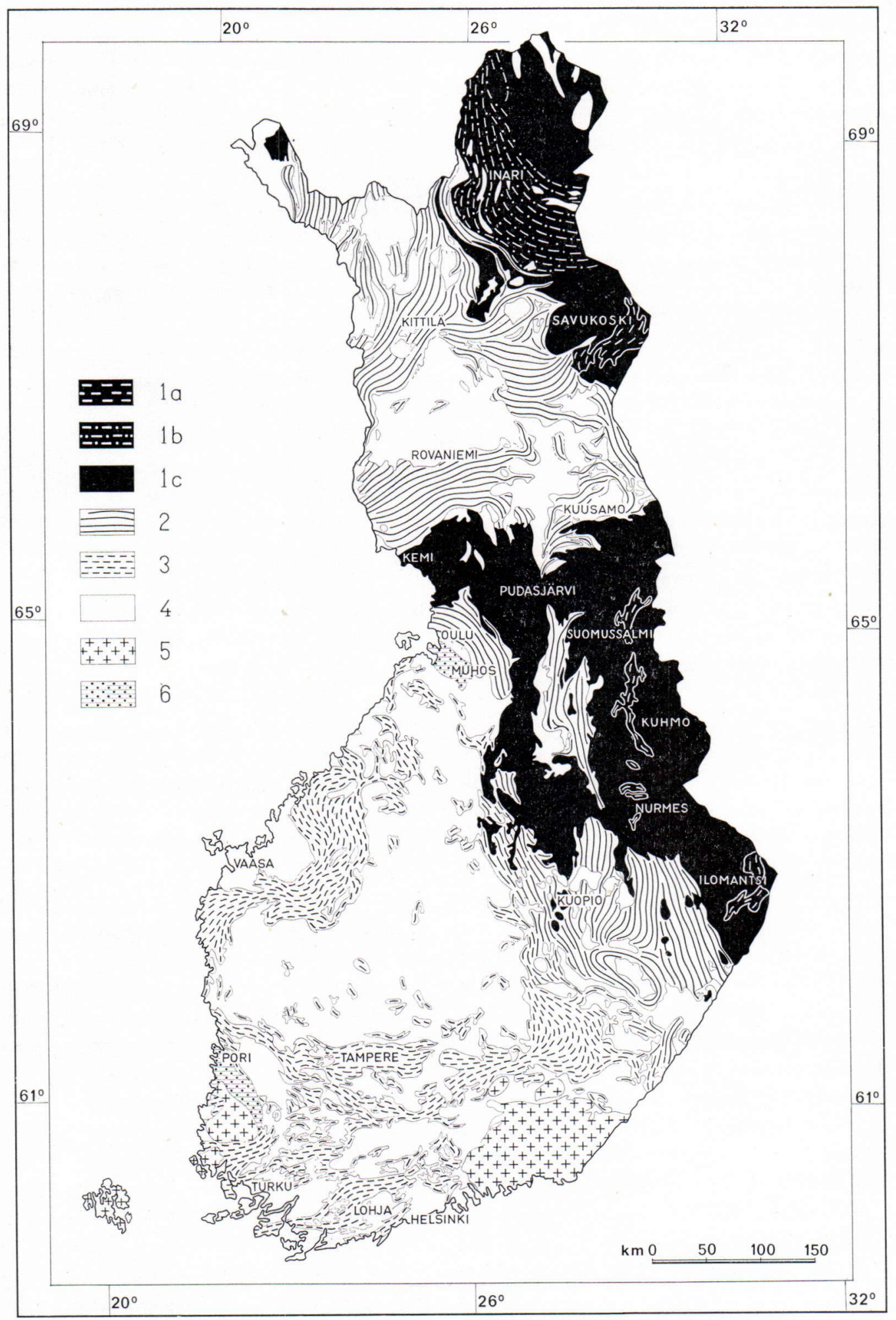

FIG. 7. Main basement units of Finland according to Simonen (1971, p. 1411). Presvecokarelidic: 1 a schist and paragneiss; 1 b granulite; 1 c orthogneiss. Svecokarelidic: 2 Karelidic schist belt; 3 Svecofennidic schist belt; 4 orogenic plutonic rocks. Later Precambrian, anorogenic: 5 rapakivi intrusions; 6 Jotnian sediments. 


\section{Shear zones}

It is obvious that the eight main trends, common to foliation, gravity isolines, fracture lines, and zones of anomalous gradients in the recent landuplift, represent the main trends of crustal shear in the central Baltic Shield. Earthquakes (Fig. 8), aligned parallel to these trends, provide additional evidence in support of this conclusion (Penttilä 1963, Teisseyre et al. 1969).

The parallelism of these features is frequently concentrated into shear zones of various widths and types. These relationships may be examined by superposing Plate 2 (in the folder) on the other maps of the paper (Figs. 3, 6, 7, and 8, and Plate 1).

Plate 2 shows some of the prominent shear zones of the basement. Each line on this map merely denotes the general position and strike of the respective zone, which, in reality, may be up to $100 \mathrm{~km}$ wide. The existence of these zones appears from the ground data as well as from Nimbus imagery ${ }^{1}$ ). Each of the main trends (I-VIII in Fig. 4) is represented by at least one line in Plate 2. In addition, there are other sets of shear zones, which fall between the main trends. Three of these latter zones are shown by dashed lines.

Zone VIa, which is parallel to the northeasterly shoreline trend of the Gulf of Bothnia, may be taken as one example to illustrate the network. The trend forms a clear peak (VI) at each of the three curves of Fig. 4. The zone appears as a lineament in Nimbus pictures (e.g., Fig. 2). It coincides with a northwesterly slope at the bedrock surface, which is indicated by an abrupt change in outcrop density (Fig. 6), and, according to Penttilä (1972), with a northwesterly slope at the Moho: In this direction, across a $100-\mathrm{km}$ wide belt underlying zone VIa, the thickness of the crust increases from 30 to $40 \mathrm{~km}$. In the zone bounded by lines VIa and VIb (Plate 2 and Fig. 7), the Svecokarelian (1 800 m.y.) schists

1) Actually, the number of major shear zones thus identified is many times greater than appears from Plate 2, the purpose of which is simply to illustrate the general idea. southeast of Vaasa, and the Presvecokarelian (2 800 m.y.) schists at Suomussalmi, as well as many structural features between the two areas, are oriented parallel to these lines (see also: Simonen 1971, p. 1410).

Line IIa indicates the position of a major shear zone, about $100 \mathrm{~km}$ wide, which is clearly visible in Figs. 2 and 6. The foliation along this zone has the same strike (Fig. 3); it is indicated partly by main and partly by subordinate maxima of the rosettes. Numerous Ni-Cu sulfide deposits, associated with basic and ultrabasic plutonic rocks, are aligned with this zone, which is characterized by wide drag folds upon steep axes, and by traces of repeated brecciation (Mikkola and Niini 1968, Talvitie 1971, Gaál 1972). The zone is seismically active (Fig. 8).

A graben formation of Jotnian red beds, $25 \mathrm{~km}$ wide and $1000 \mathrm{~m}$ thick, is situated in zone $\mathrm{IIb}$, which has been classified as an abyssal fracture by Salop and Scheinmann (1969, Fig. 4). According to Penttilä (op.cit.), the zone coincides with a ramp at the Moho, which deepens here from 30 to $35 \mathrm{~km}$ toward the northeast. Another Jotnian red-bed graben, of about same dimensions as above (Puranen 1963), falls in line with IIIa. According to Lauren (1970), this fracture zone has been the feeding channel for the neighboring rapakivi pluton (1 700 m.y.).

On the whole, comparison of Fig. 7 with Plate 2 indicates that the schist belts, and the general boundaries of the major lithologic and other basement units, are most frequently parallel to lines I-VIII of Plate 2. This seems to apply to all the Precambrian rocks from Presvecokarelian (2 800 m.y.) to Jotnian (1 300 m.y.), as well as to the Paleozoic deposits forming parts of the bottom of the Gulf of Bothnia (Winterhalter 1972). As the areas of the different rocks normally are controlled by at least two trends of the network, they are more or less polygonal.

Fold as well as fault belts belong to each of the main trends. An individual shear zone is frequently a fold belt in one part of the zone and a fault belt in another. 


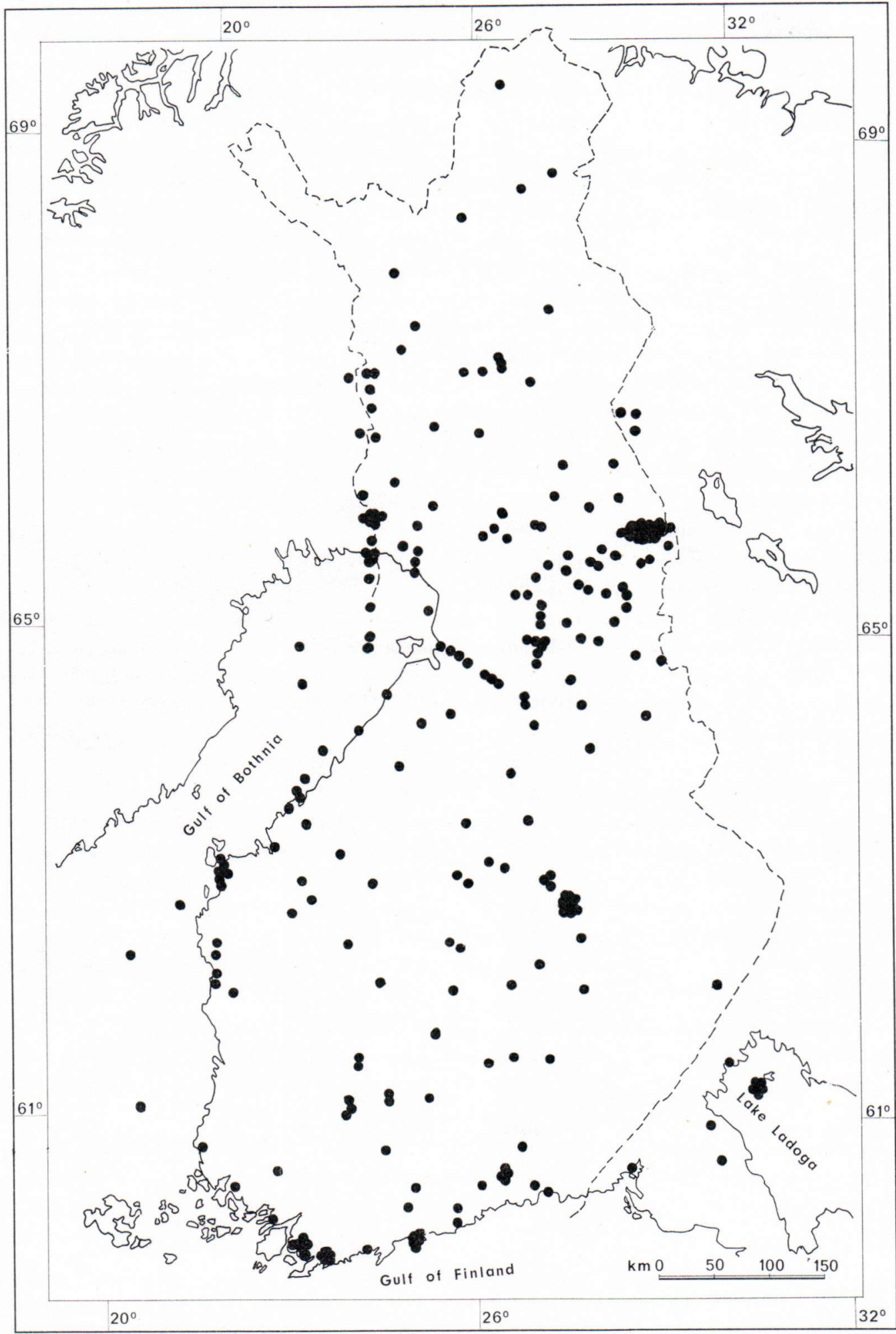

FIG. 8. Earthquake epicenters in Finland during 1610-1970. From Penttilä (1963); later events added. 
Axial culminations and depressions, mantled domes ( $c f$. , Eskola 1949, Preston 1954), and various plutons seem to be characteristic of the shear-zone intersections.

\section{Concluding remarks}

The fact that the shear-net pattern of the Svecokarelian and later rocks also appears in the Presvecokarelian basement suggests that the general block structure of the Shield antedated the Svecokarelian sedimentation. This means that the Svecokarelian geosynclines and other basins developed above a foundation consisting of more or less individually moving blocks. Movements in this block mosaic have also controlled the later development of the Shield.

The lineaments in the Nimbus imagery indicate that the major fracture zones transecting the Baltic Shield continue into the surrounding areas of Paleozoic and later rocks. The tectonic features of the whole Baltic Shield, as well as the Caledonides, seem to be in conformance with the shear-net pattern defined by these fractures (cf., Cloos 1948).
The fracture zones conform closely with great circles of the globe. In consequence, their strikes vary with geographic position, and no two zones can be exactly parallel. (Cf., Boutakoff 1952, Brock 1972.)

The great-circle extensions of these zones generally seem to conform with the bottom configuration (e.g., Johnson and Heezen 1967, p. 764) and magnetic anomalies (Avery et al. 1968) of the surrounding ocean areas. The northwestward extension of zone IIIa (Plate 2 and Fig. 6.), for instance, coincides with the Jan Mayen Fracture Zone ( $c f$. , Riddihough 1972). This suggests that the Early Precambrian shear-net or fracture system of the Baltic Shield extends over the surrounding ocean floor.

Acknowledgements - A great amount of unpublished geological data was made available for this study by the Geological Survey of Finland, by the Outokumpu Co, and the Suomen Malmi Co. The Meteorological Institute of Finland and the Radio Laboratory of Helsinki University of Technology provided the weather satellite pictures. Elja Arjas reviewed the statistical treatments used in this report. Hannu Autio designed the computer programs employed. Riitta Virtanen assisted in drawing the pictures. Financial support was received from the Academy of Finland and the Jenny and Antti Wihuri Foundation.

\section{REFERENCES}

Aarnisalo, J. (1969) Suomen gravimetristen konttuurien frekvenssisuunnat. [Direction frequency of gravity isolines, Finland]. Manuscr., Arch. Geol. Min., Univ. Helsinki.

- (1971) Kallioperän lohkorakenne ja deformaatiovyöhykkeet Suomessa. [Block structure and deformation zones in Finland]. Manuscr., Arch. Geol. Min., Univ. Helsinki.

- Söderholm, B. and Tuominen, H. V. (1969) Om berggrundens deformation i Finland (Abs.). [Bedrock deformation in Finland]. IX Nordiske geologiske vintermøde, Lyngby, 5-7 Januar 1970, Program og resumeer av foredrag, København, p. 17.

Avery, O. E., Burton, G. B. and Heirtzler, J. R. (1968) An aeromagnetic survey of the Norwegian Sea. J. Geophys. Res., 73, 14, 4 583-4 600.

BAdgley, P. C. (1965) Structural and tectonic principles. Harper \& Row, Publishers, New York, 521 p.
Bodechtel, J. and Lammerer, B. (1973) New aspects on the tectonic of the Alps and the Apennines revealed by ERTS-1 data. NASA SP-327; Symp. signif. results obt. ERTS-1, Vol. I - Sect. A, 493-499.

Bogdanov, V. I. and Kнодотоv, Yu. D. (1967) Some patterns of the block structure of the Baltic crystalline shield. Geotectonics, 1, 53-55.

Boutakoff, N. (1952) The great-circle stress pattern of the earth. Aust. J. Sci. 14, 4, 108-111.

Brock, B. B. (1972) A global approach to geology. A. A. Balkema, Cape Town, 365 p.

Cloos, H. (1948) The ancient European basement blocks. Trans. Am. Geophys. Union 29, 1, 99-103.

EskolA, P. (1949) The problem of mantled gneiss domes. Quart. Jour. Geol. Soc. London 104, 461-476.

GAÁl, G. (1972) Tectonic control of some Ni-Cu deposits in Finland. 24th Int. Geol. Congr. - Sect. 4, 215-224. Härme, M. (1960) Suomen geologinen yleiskartta. The 
general geological map of Finland. Lehti-Sheet B 1, Turku. Kivilajikartan selitys. English summary. Geol. tutkimusl. Geol. Surv. Finland, 78 p.

- (1961) On the fault lines in Finland. C. R. Soc. géol. Finlande. 33, 25, 437-444.

- (1963) On the shear zones and fault lines on Finnish Precambrian strata. Fennia 89, 1, 29-32.

- (1966) On the block character of the Finnish Precambrian basement. Ann. Acad. Sci. Fenn., A. III, $90,133-134$.

Honkasalo, T. (1960) On the land uplift in Fennoscandia. Geophysica 7, 117-119.

- (1962) Gravity survey of Finland in the years 19451960. Bouguer anomalies. Publ. Finn. Geod. Inst., 55.

Hүyррӓ, E. (1951) Kuvia Salpausselän rakenteesta. Summary: On the structure of the First Salpausselkä. Geologi 3, 2-3, 5-7.

- (1954) Åsarnas uppkomst. [On the origin of eskers]. Geologi 6, 5, 45.

Johnson, G. L. and Heezen, B. C. (1967) Morphology and evolution of the Norwegian-Greenland Sea. DeepSea Res. 14, 755-771.

KäÄriäIneN, E. (1963) Land uplift in Finland computed by the aid of precise levellings. Fennia 89, 1, 15-20.

- (1966) Land uplift in Finland as computed with the aid of precise levellings. Ann. Acad. Sci. Fenn., A. III, $90,187-190$.

Lathram, E. H. (1972) Nimbus IV view of the major structural features of Alaska. Science 175, 1 423-1 427.

LAURÉN, L. (1970) An interpretation of the negative anomalies associated with the rapakivi granites in the Jotnian sandstone in southern Finland. Geol. Fören. Stockholm Förh. 92(1), 540, 21-35.

Marmo, V. (1959) Topografiset piirteet geologisen rakenteen ilmentäjinä. Summary: The topographical features as indicator of the geological structures. Terra $71,2,84-98$.

Miknola, A. and Nirni, H. (1968) Structural position of the ore-bearing areas in Finland. Bull. Geol. Soc. Finland 40, 17-33.

PaArma, H. (1963) On the tectonic structure of the Finnish basement, especially in the light of geophysical maps. Fennia 89, 1, 33-36.

- and MARmo, V. (1961) Eräistä suurrakenteista Suomen geologiaan sovellettuina. Summary: On some large structures with an application into geology of Finland. Terra 73, 2, 78-86.

Pentrilü, E. (1963) Some remarks on earthquakes in Finland. Fennia 89, 1, 25-28.

- (1972) Crustal structure in Fennoscandia from seismological and gravimetric observations. Ann. Acad. Sci. Fenn., A. III, 110, 38 p.

Petrov, A. I. (1970) Old faults in the eastern part of the Baltic shield. Dokl. Akad. Nauk SSSR 191, 56-59.
Preston, J. (1954) The geology of the Precambrian rocks of the Kuopio district. Ann. Acad. Sci. Fenn., A. III, 40, $111 \mathrm{p}$.

Puranen, M. (1963) A geophysical investigation of the Satakunta sandstone area in South-Western Finland. Geoexploration 1, 1, 6-15.

Riddihough, R. P. (1972) Regional magnetic anomalies and geology in Fennoscandia: a discussion. Can. J. Earth Sci. 9, 3, 219-232.

Romber G, F. E. (1958) Key variables in gravity. Geophysics $23,4,684-700$.

Sabatini, R. R., Rabchevsky, G. A. and Sissala, J. E. (1971) Nimbus Earth resources observations. Techn. Rep. 2. Prep. for NASA, GSFC, Greenbelt, Md. (Contr. No. NAS 5-21617). Allied Res. Assoc., Inc., Concord, Mass., 256 p.

Salop, L. I. and Scheinmann, Yu. M. (1969) Tectonic history and structures of platforms and shields. Tectonophysics 7, 5-6, 565-597.

Sauramo, M. (1929) The Quaternary geology of Finland. Bull. Comm. géol. Finlande 96, 110 p.

Simonen, A. (1971) Das finnische Grundgebirge. Geol. Rundsch. 60, 4, $1406-1421$.

Söderholm, B. (1970) Frekvensanalys av skiffrighetsstrykningarna i Finlands berggrund. [Strike-frequency analysis of foliation in the Precambrian of Finland]. Manuscr., Arch. Geol. Min., Univ. Helsinki.

Talvitie, J. (1971) Seismotectonics of the Kuopio region, Finland. Bull. Comm. géol. Finlande 248, 41 p.

Teisseyre, R., Penttillä, E., Tuominen, H. V. and Vesanen, E. (1969) The horizontal spread of cratonic earthquakes and the corresponding block movements. Geophysica 10, 55-68.

Tuominen, H. V. (1957) The structure of an Archean area: Orijärvi, Finland. Bull. Comm. géol. Finlande 177, 32 p. - (1962) On the role of faulting, a reply. C. R. Soc. géol. Finlande 34, $1-4$.

- (1966) On synkinematic Svecofennian plutonism. C. R. Soc. géol. Finlande 38, 387-392.

- (1973a) Use of satellite pictures for determining major geologic structures relevant for ore prospecting, Finnish Lapland (SR-580-3). IEEE Transact. Geosci. Electron. GE-11, 1, 43.

- (1973b) Major crustal fractures in the Baltic Shield. NASA Earth Resour. Surv. Program, Wkly abstr. 93-73-05, 11.

- and Söderholm, B. (1966) Trends of fracture lineaments and rock foliation in the Turku Archipelago. Geologi 18, 10, 131-133.

Winterhalter, B. (1972) On the geology of the Bothnian Sea, an epeiric sea that has undergone Pleistocene glaziation. Geol. Surv. Finland, Bull. 258, 66 p.

Manuscript received, April 14, 1973. 
PLATE 1 Bull. Geol. Soc. Finland 45, 205-217 (1973).

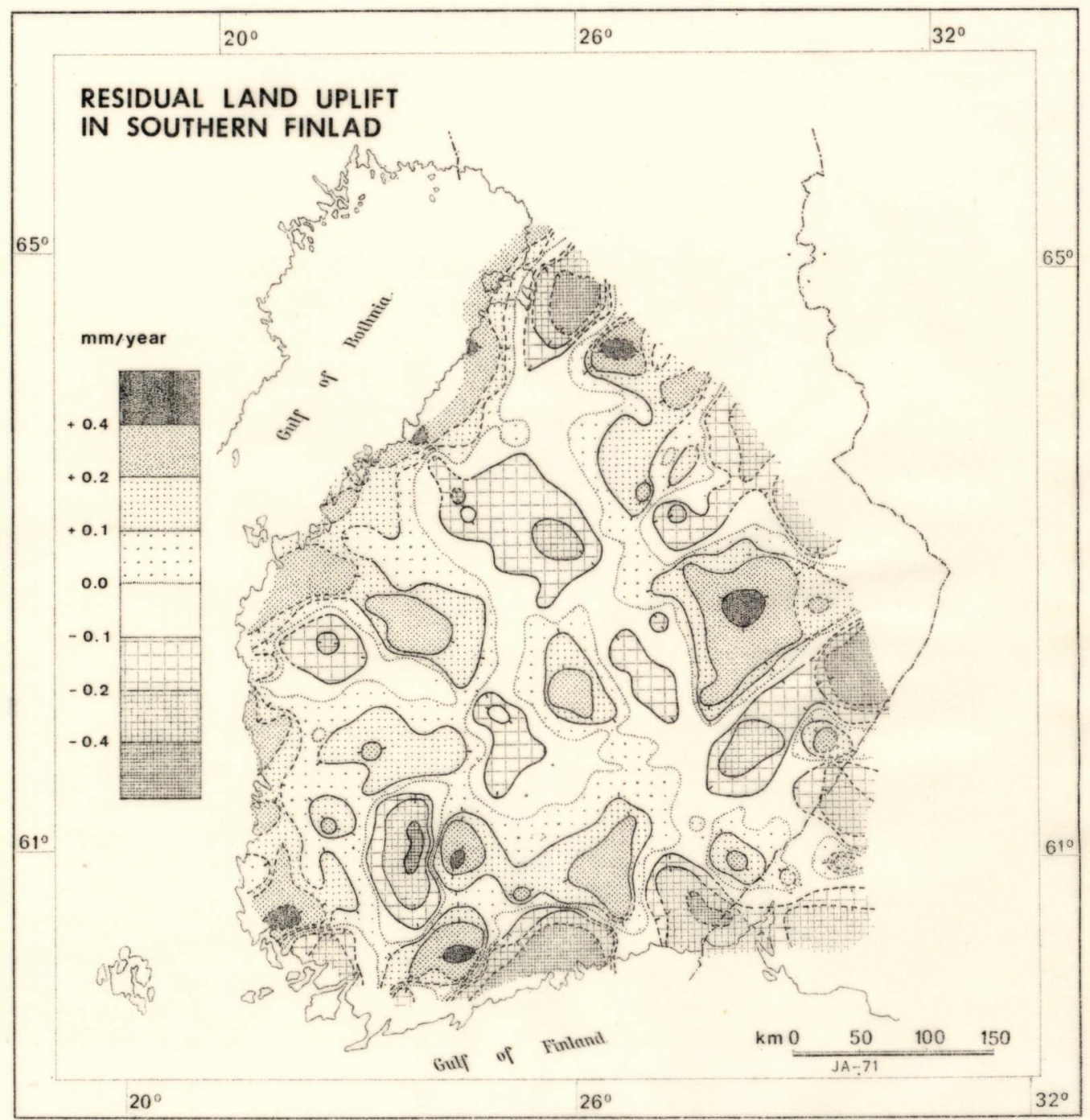

Heikki V. Tuominen, Jussi Aarnisalo and Bengt Söderbolm: Tectonic patterns in the central Baltic Shield. 
PLATE 2 Bull. Geol. Soc. Finland 45, 205-217 (1973).

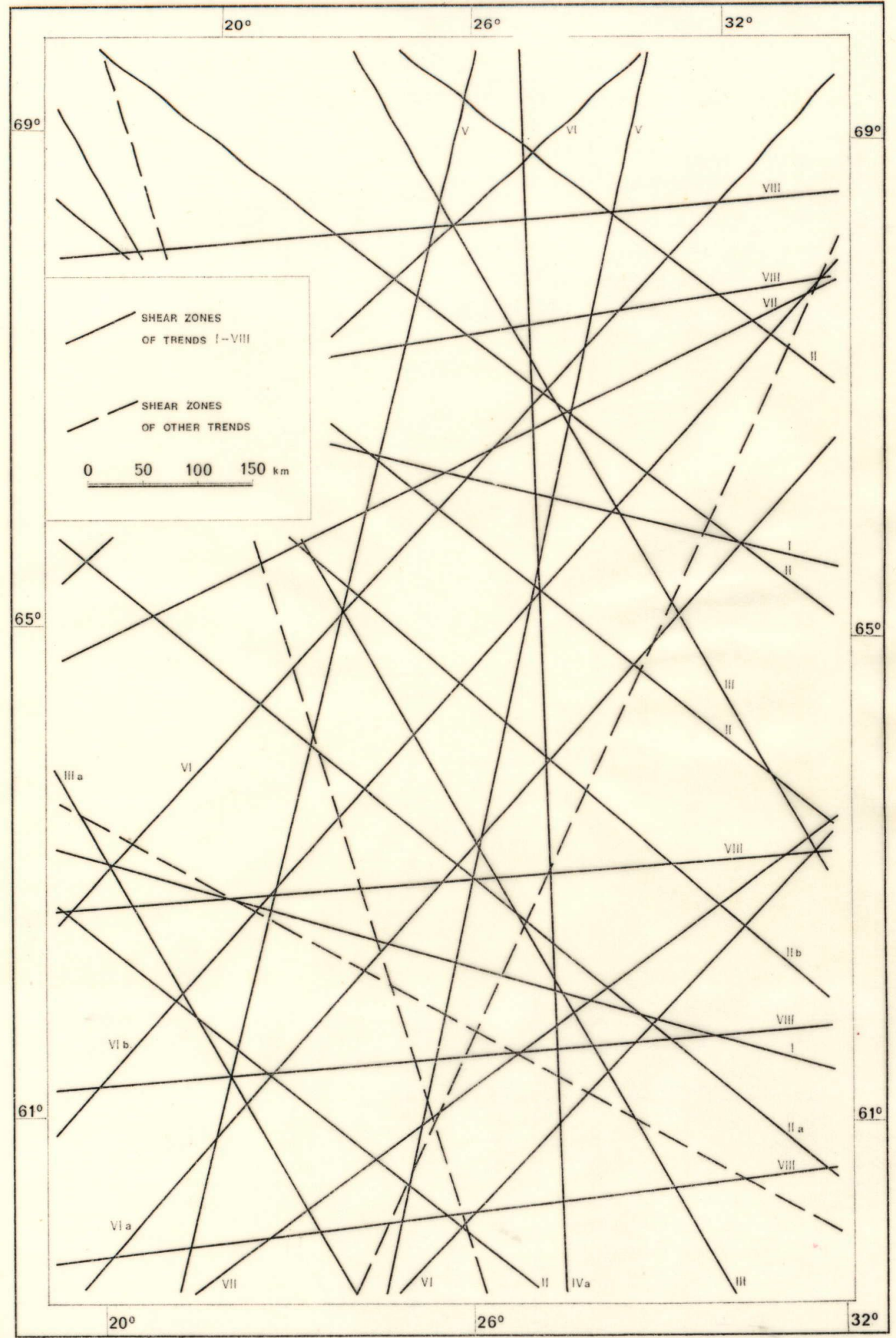

Diagrammatic map showing some major shear zones in the central Baltic Shield.

Heikki V. Tuominen, Jussi Aarnisalo and Bengt Söderbolm: Tectonic patterns in the central Baltic Shield. 